\title{
BEST SELECTION OF PROJECT PORTFOLIO USING FUZZY AHP AND FUZZY TOPSIS
}

\author{
UDC: 005.8:510.6 \\ Original Scientific Paper

\begin{abstract}
Mohammad ANISSEH ${ }^{1}$, Fatemeh HEMMATI ${ }^{2}$, Mohammad Reza SHAHRAKI ${ }^{3}$
\end{abstract} \\ ${ }^{1}$ Imam Khomeini International University, Department of Industrial Management, Iran \\ E-mail: manisseh@soc.ikiu.ac.ir \\ ${ }^{2}$ Buein Zahra Technical University, Mechanical and Industrial Engineering Department, Iran \\ ${ }^{3}$ University of Sistan and Baluchestan, Department of Industrial Management, Zahedan, Iran \\ Paper received: 05.04.2018.; Paper accepted: 28.05.2018.

\begin{abstract}
Choosing the optimal portfolio for the project is one of the most important and strategic decisions in most organizations, especially project-based organizations. The issue of the project selection is a periodic activity in order to choose the appropriate and optimal portfolio from the proposed projects and ongoing projects within the organization which can meet organizational goals without waste of the resources and taking into account certain constraints. Consequently, the aim of this paper is to select the best project portfolio by using fuzzy AHP and fuzzy TOPSIS methods. The forgoing methods have been used in a case study, and the result and data have been evaluated from different points of view.
\end{abstract}

Keywords: Project, Project Portfolio, Project Portfolio Management, Fuzzy AHP, Fuzzy TOPSIS.

\section{INTRODUCTION}

In today's competitive environment only organizations that properly utilize existing opportunities with respect to their constraints can survive; and others will inevitably be condemned to fall over the time. The use of situations, prior to recognizing situations, requires full understanding of the strengths and weaknesses, abilities and limitations. One of the ways that can help organizations to choose the best positions is the theme of project portfolio management. Project portfolio management by collecting information from different parts of the organization, and collecting project information help managers to make the right decision. Therefore, one of the important issues in project management is the best selection of project portfolio, (Rabieh \& Faddaie, 2015). A project portfolio or portfolio is a set of projects, plans or operations that are grouped together to make effective management of activities and to achieve strategic goals, (Ravanshadnia \& Jahromi, 2015). Project portfolio has been created to achieve one or more corporate strategy and goals, and may consist of a set of past, present, scheduled and future portfolio (PMI). The issue of selecting a project and its related activities is one of the important activities in many organizations, especially contracting companies and project-based construction companies. In selecting a project portfolio, the most important issue that is to be asked is whether the portfolio should include what projects. The more choosing the lightweight portfolio projects, the more likely the missions of the organization will be (Alinezhad \& Simiari, 2013).

Decision making problems are one of the most important issues in all sciences. Fan, $\mathrm{Ma}$ and Zhang (2002) and Chuu (2009) stated that human beings are faced with issues of decision making that basically involves choosing the most-preferred alternatives from a limited set of alternatives to obtain certain-predefined objectives. It is the process to find the best alternative from all feasible alternatives, (Bashiri \& Badri, 2010). Decisions in the public and private sector decision-making often involve the assessment and ranking of available alternatives or decision options based on multicriteria, (Hwang \& Yoon, 1995). Multi criteria decision making (MCDM) in the field is one of the most widely used methods, (Yeh \& Chang, 2008). 
The MCDM goal is to choose the best alternative from some mutually exclusive options regarding different criteria decided by the decision maker.

\section{FUZZY SET THEORY}

Zadeh (1965) presented fuzzy set theory to cope with the ambiguity of human thought. Fuzzy set allows partial membership unlike the classical set. Classical set theory concepts are made based on the member or non-member. There is a clear, sharp, and crisp boundary exists between a member and non-member in this set, so the classical set theory cannot describe many realworld applications (Ertuğrul \& Karakaşoğlu, 2009). Zadeh (1965) proposed to use values ranging from 0 to 1 for showing the membership of the objects in a fuzzy set. Complete non membership is represented by 0 , and complete membership as 1 . Values between 0 and 1 represent intermediate degrees of membership. "Not very clear", "probably so", "very likely", these terms of expression can be heard very often in daily life and their commonality is that they are more or less tainted with uncertainty. With different daily decision making problems of diverse intensity, the results can be misleading if the fuzziness of human decision making is not taken into account, (Tsaur, Chang, \& Yen, 2002). Fuzzy sets theory providing a more widely frame than classic sets theory, has been contributing to capability of reflecting real world (Ertuğrul \& Tuş, 2007). Fuzzy sets and fuzzy logic are powerful mathematical tools for modeling: uncertain systems in industry, nature and humanity; and facilitators for common-sense reasoning in decision making in the absence of complete and precise information. Their role is significant when applied to complex phenomena not easily described by traditional mathematical methods, especially when the goal is to find a good approximate solution.

Definition 1. Let $U$ be the universe of discourse and $u$ a generic element of $U$, then $U=\{u\}$. A fuzzy subset $\tilde{A}$, defined in $U$, is:

$$
\widetilde{A}=\left\{\left(u, \mu_{\tilde{A}}(u)\right) ; u \in U\right\},
$$

where $\mu_{\tilde{A}}(u)$ is designated as membership function or membership grade (also designated as degree of compatibility or degree of truth) of $u$ in $\tilde{A}$. The membership function associates with each element $u$, of $U$, a real number $\mu_{\tilde{\imath}}(u)$, in the interval $[0,1]$, (Simões-Marques, Ribeiro, \& Gameiro-Marques, 2000).

Definition 2. Dubois and Prade (1978) proposed the triangular fuzzy number and defined it as follows: A is a fuzzy number, if A is normal and convex, (Liu \& Wu, 2007). A triangular fuzzy numbers can be expressed as $\mathrm{M}=(l, m, u)$, where $l$ $\leq m \leq u$, in which $l \leq m \leq u$. In the fuzzy event, parameters $(l, m, u)$ are the smallest, promising, and the largest possible value, correspondingly. Equation 3 describes the triangular fuzzy number membership function $\mathrm{M}$, when $l=m=u$, it is a nonfuzzy number by agreement as shown in Figure 1, (Önüt, Kara, \& Efendigil, 2008).

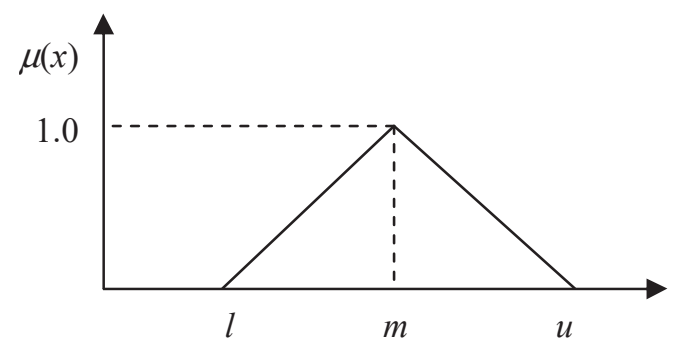

Figure 1: Triangular fuzzy membership function

$$
\mu_{m}(x)=\left\{\begin{array}{cc}
0 & x<l \\
\frac{(x-l)}{(m-l)} & l \leq x \leq m \\
\frac{(u-x)}{(u-m)} & m \leq x \leq u \\
0 & x>u
\end{array}\right.
$$

Definition 3. The main operational laws for two triangular fuzzy numbers $M_{1}$ and $M_{2}$ are as follows, (Kaufmann \& Gupta, 1991).

$$
\begin{aligned}
& M_{1}+M_{2}=\left(l_{1}+l_{2}, m_{1}+m_{2}, u_{1}+u_{2}\right), \\
& M_{1} \times M_{2}=\left(l_{1} \times l_{2}, m_{1} \times m_{2}, u_{1} \times u_{2}\right), \\
& \omega \times M_{1}=\left(\omega l_{1}, \omega m_{1}, \omega u_{1}\right), \\
& \omega>0, \omega \in \mathrm{R}, \\
& M_{1}^{-1}=\left(\frac{1}{u_{1}}, \frac{1}{m_{1}}, \frac{1}{l_{1}}\right) .
\end{aligned}
$$

Definition 4. A variable with values of word or sentences in an artificial language is defined as linguistic variable, (Wang, Cheng, \& Huang, 2009). After recognition of the cardinality of the linguistic terms, linguistic and semantics terms 
must be arranged. There are various possibilities to fulfil this work. Considering all the terms distributed on a scale involves directly supplying the term set where the total order is defined, (Herrera \& Martínez, 2001). For instance, a set of seven terms can be presented in Table 1 .

Table 1: Linguistic variables for the ratings

\begin{tabular}{|l|c|r|}
\hline Very Poor & $V P$ & $(0,0,1)$ \\
\hline Poor & $P$ & $(0,1,3)$ \\
\hline Medium Poor & $M P$ & $(1,3,5)$ \\
\hline Fair & $F$ & $(3,5,7)$ \\
\hline Medium Good & $M G$ & $(5,7,9)$ \\
\hline Good & $G$ & $(7,9,10)$ \\
\hline Very Good & $V G$ & $(9,10,10)$ \\
\hline
\end{tabular}

\section{THE PROPOSED METHOD}

Let $A=\left\{A_{1}, A_{2}, \ldots, A_{m}\right\}$ be a discrete set of alternatives, $D=\left\{D_{1}, D_{2}, \ldots, D_{t}\right\}$ be the set of decision makers, and $\lambda=\left(\lambda_{1}, \lambda_{2}, \ldots, \lambda_{t}\right)$ be the weight vector of decision makers, where $\lambda_{k} \geq 0, k=1,2, \ldots, t$, and $\sum_{k=1}^{t} \lambda_{k}=1$. Let $C=\left\{C_{1}, C_{2}, \ldots, C_{n}\right\}$ be the set of attributes, and $w=\left(w_{1}, w_{2}, \ldots, w_{n}\right)$ be the weight vector of attributes, where $w_{n} \geq 0, n=1,2, \ldots, j, \sum_{n=1}^{j} w_{n}=1$. The fuzzy group decision problem can be concisely expressed as matrix format:

$$
\begin{aligned}
& \begin{array}{llll}
C_{1} & C_{2} & \cdots & C_{n}
\end{array} \\
& \tilde{D}_{k}=\begin{array}{c}
A_{1} \\
A_{2} \\
\vdots \\
A_{m}
\end{array}\left[\begin{array}{cccc}
\tilde{x}_{11} & \tilde{x}_{12} & \cdots & \tilde{x}_{1 n} \\
\tilde{x}_{21} & \tilde{x}_{22} & \cdots & \tilde{x}_{2 n} \\
\vdots & \vdots & \vdots & \vdots \\
\tilde{x}_{m 1} & \tilde{x}_{m 2} & \cdots & \tilde{x}_{m n}
\end{array}\right]
\end{aligned}
$$

$\tilde{W}=\left[\tilde{w}_{1}, \tilde{w}_{2}, \cdots, \tilde{w}_{n}\right]$ where $\tilde{x}_{i j}^{k}$ and $\tilde{w}_{j}^{k}$ are linguistic variables that can be shown by fuzzy numbers, (Mahdavi, Mahdavi-Amiri, Heidarzade, \& Nourifar, 2008).

Step 1. Identify the evaluation criteria that are connected to system goals.

Step 2. Develop alternatives to achieve the systems goals (alternatives generation).

Step 3. Evaluate alternatives in terms of criteria (the values of the criterion functions are fuzzy).

Step 4. Identify the weights of criteria and the weights of decision makers based on fuzzy AHP method (the values of the weights can be crisp or fuzzy).

Table 2: Saaty's Crips Scale and Fuzzified Scale for Pairwise Comparison

\begin{tabular}{|c|l|c|c|}
\hline $\begin{array}{c}\text { Saaty's Crips } \\
\text { Scale }\end{array}$ & $\begin{array}{c}\text { Judgment } \\
\text { Definition }\end{array}$ & $\begin{array}{c}\text { Triangular } \\
\text { Fuzzy Scale }\end{array}$ & $\begin{array}{c}\text { Triangular Fuzzy } \\
\text { Reciprocal Scale }\end{array}$ \\
\hline 1 & Equal Importance & $(1,1,2)$ & $(1 / 2,1,1)$ \\
\hline 2 & Least Important & $(1,2,3)$ & $(1 / 3,1 / 2,1)$ \\
\hline 3 & Weak Importance & $(2,3,4)$ & $(1 / 4,1 / 3,1 / 2)$ \\
\hline 4 & Less Strong Importance & $(3,4,5)$ & $(1 / 5,1 / 4,1 / 3)$ \\
\hline 5 & Strong Importance & $(4,5,6)$ & $(1 / 6,1 / 5,1 / 4)$ \\
\hline 6 & More Strong Importance & $(5,6,7)$ & $(1 / 7,1 / 6,1 / 5)$ \\
\hline 7 & Very Strong Importance & $(6,7,8)$ & $(1 / 8,1 / 7,1 / 6))$ \\
\hline 8 & Extremely Importance & $(7,8,9)$ & $(1 / 9,1 / 8,1 / 7)$ \\
\hline 9 & Very Extremely Importance & $(8,9,9)$ & $(1 / 9,1 / 9,1 / 8)$ \\
\hline
\end{tabular}

- Establish pairwise comparison matrix of the criteria using Triangular Fuzzy Numbers. A 9point scale was used to describe the relative importance of criteria with respect to the goal, (Tsaur et al., 2002) as shown in Table 2.

- Convert to crisp value. Each fuzzy evaluation of every criterion has to be converted into crisp value. It was done as in the following step. The relative weight of all evaluation criteria are still in the form of triangular fuzzy number and need to defuzzify using Center of Gravity, (Chou, Chang, \& Shen, 2008).

$$
W_{i}=\frac{\left(u_{i}-l_{i}\right)+\left(m_{i}-l_{i}\right)}{3}+l_{i}
$$

- Finally, in order to effectively compare the relative importance of the evaluation criteria, the defuzzified priority values are normalized using: 


$$
N W_{i}=\frac{W_{i}}{\sum_{i}^{n} W_{i}}
$$

- Consistency ratio (CR) is required to determine whether the weight assign by the decision maker is correct or not. $\mathrm{CR}<0.1$ indicates consistent judgment in pairwise comparisons. $C R$ is calculated using equation 7 and 8 (Ahmad, Kasim, \& Rajoo, 2016).

$$
\begin{aligned}
& C I=\frac{\lambda \max \max -n}{n-1} \\
& C R=\frac{C I}{R I}
\end{aligned}
$$

Step 5. Construct fuzzy decision matrix. Each $\tilde{x}_{i j}^{k}$ is supposed fuzzy number in the fuzzy decision matrix.

Step 6. The normalized fuzzy decision matrix is constructed as follows for triangular fuzzy numbers, (Kahraman, Ateş, Çevik, Gülbay, \& Erdoğan, 2007; Tsao, 2006):

$$
\tilde{R}=\left[\tilde{r}_{i j}\right]_{m \times n}
$$

If $\left(\tilde{x}_{i j}, i=1,2, \ldots, m, j=1,2, \ldots, n\right)$ are triangular fuzzy numbers, then the normalization process can be performed by, (Wang at al., 2009):

$$
\begin{aligned}
& \tilde{r}_{i j}=\left(\frac{a_{i j}}{c_{j}^{*}}, \frac{b_{i j}}{c_{j}^{*}}, \frac{c_{i j}}{c_{j}^{*}}\right) i=1,2, \ldots, m, j \in B \\
& \tilde{r}_{i j}=\left(\frac{a_{j}^{-}}{c_{i j}}, \frac{a_{j}^{-}}{b_{i j}}, \frac{a_{j}^{-}}{a_{i j}}\right) i=1,2, \ldots, m, j \in C
\end{aligned}
$$

Where $\mathrm{B}$ and $\mathrm{C}$ are the set of benefit criteria and cost criteria, respectively, and

$$
\begin{array}{ll}
c_{j}^{*}=\operatorname{m~ax}_{i} & c_{i j} \quad j \in B \\
a_{j}^{-}=\min & a_{i j} \\
j \in C
\end{array}
$$

(Mahdavi et al., 2008; Saghafian \& Hejazi, 2005; Wang \& Lee, 2007).

Step 7. DMs fuzzy decision matrices are defuzzified and aggregated as follows for triangular fuzzy numbers:

$$
g_{i j}=\left[\left[\prod_{k=1}^{t}\left(a_{i j}^{(k)}\right)^{\lambda_{a}^{(k)}}\right]^{\frac{1}{N}} \cdot\left[{ }_{k=1}^{t}\left(b_{i j}^{(k)}\right)^{\lambda_{b}^{(k)}}\right]^{\frac{1}{N}} \cdot\left[{ }_{k=1}^{t}\left(c_{i j}^{(k)}\right)^{\lambda_{c}^{(k)}}\right]^{\frac{1}{N}}\right]^{\frac{1}{n}}
$$

Where $n=3$ for triangular fuzzy numbers and $\tilde{\lambda}^{(k)}=\left(a_{i j}^{(k)}, b_{i j}^{(k)}, c_{i j}^{(k)}\right)$ is the DMs viewpoints importance weights where $\tilde{\lambda}^{(k)} \geq 0, k=1,2, \ldots, t$, and $\sum_{k=1}^{t} \tilde{\lambda}^{(k)}=1$, so $\sum_{k=1}^{t} \tilde{\lambda}^{(k)}=N$. Or

$$
g_{i j}=\left(\frac{1}{n}\right) \cdot\left[\prod_{k=1}^{t}\left(a_{i j}^{(k)}+b_{i j}^{(k)}+c_{i j}^{(k)}\right]^{\frac{1}{N}}\right.
$$

Where $n=3$ for triangular fuzzy numbers and $\lambda^{(k)}=\left(\lambda^{1}, \lambda^{2}, \ldots, \lambda^{t}\right)$ is the weight vector of decision makers, where $\lambda^{(k)} \geq 0, k=1,2, \ldots, t$, and $\sum_{k=1}^{t} \lambda^{(k)}=1$, so $\sum_{k=1}^{t} \lambda^{(k)}=N$. Or

$$
\left.g_{i j}=\left[\prod_{k=1}^{t}([(u-l)+(m-l)] / 3+l]^{(k)}\right)^{\lambda^{(k)}}\right]^{\frac{1}{N}}
$$


Where $\lambda^{(k)}=\left(\lambda^{1}, \lambda^{2}, \ldots, \lambda^{t}\right)$ is the weight vector of decision makers, and $\lambda^{(k)} \geq 0, k=1,2, \ldots, t$, and $\sum_{k=1}^{t} \lambda^{(k)}=1$, so $\sum_{k=1}^{t} \lambda^{(k)}=N$, (Anisseh, Piri,

Shahraki, \& Agamohamadi, 2012).

Step 8. The weighted normalized decision matrix is calculated as following:

$$
V=N_{D} \cdot W_{n \times n}=\left|\begin{array}{ccc}
V_{1 i}, \ldots & V_{1 j}, \ldots & V_{1 n} \\
\vdots & \vdots & \vdots \\
V_{m 1}, \ldots & V_{m j}, \ldots & V_{m n}
\end{array}\right|
$$

where $w_{j}$ is the weight of the $i$ th attribute or criterion, and $\sum_{j=1}^{n} w_{j}=1$.

Step 9. Verify the positive ideal and negative ideal solution:

$$
\begin{aligned}
& A^{+}=\left\{\left(\max _{j} v_{i j} \mid i \in I\right),\left(\min _{j} v_{i j} \mid i \in J\right) \mid i=1,2, \ldots, n\right\} \\
& A^{-}=\left\{\left(\min _{j} v_{i j} \mid i \in I\right),\left(\max _{j} v_{i j} \mid i \in J\right) \mid i=1,2, \ldots, m\right\}
\end{aligned}
$$

where $I$ is associated with benefit criteria, and $J$ is associated with cost criteria.

Step 10. The separation measures are calculated utilizing the $n$-dimensional Euclidean distance. The separation measure of each alternative from the ideal solution is presented as:

$$
d_{i^{+}}=\left\{\sum_{j=1}^{n}\left(v_{i j}-v_{j}^{+}\right)^{2}\right\}^{\frac{1}{2}}, i=1,2, \ldots, m
$$

Similarly, the separation from the negative ideal solution is given as:

$$
d_{i^{-}}=\left\{\sum_{j=1}^{n}\left(v_{i j}-v_{j}^{-}\right)^{2}\right\}^{\frac{1}{2}}, i=1,2, \ldots, m
$$

Step 11. The relative closeness to the ideal solution is calculated.

$$
\begin{aligned}
& c l_{i^{+}}=\frac{d_{i^{-}}}{\left(d_{i^{+}}+d_{i^{-}}\right)}, \\
& 0 \leq c l_{i^{+}} \leq 1, i=1,2, \ldots, m
\end{aligned}
$$

Step 8. The alternatives' ranking orders are determined according to the closeness coefficient, and the best alternative is selected between a set of feasible alternatives.

\section{EMPIRICAL STUDY}

This study was performed in Qazvin municipality in three phases: Identifying the evaluation criteria (effective factors for selecting the best project portfolio), identifying the weights of criteria (effective factors' weights) and finally prioritizing of the projects. Five projects (alternatives) $A=\left\{A_{1}, A_{2}, \ldots, A_{5}\right\}$ are evaluated using the linguistic variables as follows: Building under construction of the municipality, Rajaie bridge, Nokhbegan footbridge, Aqueduct construction and park construction. At first stage an expert team of five members from deputy of construction was formed.

At the second stage using fuzzy Delphi method with its five stages, the criteria and the sub criteria (Effective factors) based on expert viewpoints were extracted as tabulated in Table 3. and Table 4. based on the linguistic variables.

Next, the expert team determines weight importance of the criteria by using fuzzy AHP method in step 4 as shown in Table 5. Five projects (alternatives) are evaluated using the linguistic variables by five DMs whose weight are equal under these 32 attributes, as listed in Table 5. Linguistic evaluations are converted into triangular fuzzy numbers to construct a fuzzy decision matrix (shown in Table 4).

Regarding the Table 4, and the continuation of step six of the proposed algorithm, alternatives were classified by Eq. (18) as follows in Table 6. 
Table 3: Average views of experts in comparing general factors with each other

\begin{tabular}{|l|c|c|c|c|}
\hline \multicolumn{1}{|c|}{ Criteria } & $\begin{array}{c}\text { Effect of } \\
\text { existing } \\
\text { project portfolio }\end{array}$ & $\begin{array}{c}\text { Project } \\
\text { specifications }\end{array}$ & $\begin{array}{c}\text { Environmental, social } \\
\text { and political } \\
\text { considerations }\end{array}$ & $\begin{array}{c}\text { Organizational } \\
\text { considerations }\end{array}$ \\
\hline Effect of existing project portfolio & $(1,1,1)$, & $(0.47,0.63,1.01)$ & $(0.56,0.8,1.4)$ & $(0.58,0.84,1.58)$ \\
\hline Project specifications & $(1.2,1.7,2.2)$ & $(1,1,1)$, & $(0.49,0.67,1.06)$ & $(059,0.86,1.6)$ \\
\hline $\begin{array}{l}\text { Environmental, social and } \\
\text { political considerations }\end{array}$ & $(0.83,1.3,1.8)$ & $(1.08,1.6,2.08)$ & $(1,1,1)$, & $(0.49,0.67,1.06)$ \\
\hline Organizational considerations & $(0.83,1.3,1.8)$ & $(0.75,1.25,1.75)$ & $(1.08,1.6,2.08)$ & $(1,1,1)$, \\
\hline
\end{tabular}

Table 4: The triangular fuzzy numbers decision matrix

\begin{tabular}{|c|c|c|c|c|c|c|}
\hline & Criteria & $\mathbf{A 1}$ & $\mathbf{A 2}$ & $\mathbf{A 3}$ & $\mathbf{A 4}$ & $\mathbf{A 5}$ \\
\hline \multirow{4}{*}{ D1 } & $C_{1}$ & $(0.3,0.45,0.6)$ & $(0.3,0.45,0.6)$ & $(0.3,0.45,0.6)$ & $(0.3,0.45,0.6)$ & $(0.3,0.45,0.6)$ \\
\cline { 2 - 7 } & $C_{\vdots}$ & $\vdots$ & $\vdots$ & $\vdots$ & $\vdots$ & $\vdots$ \\
\cline { 2 - 7 } & $C_{32}$ & $(0.6,0.7,0.8)$ & $(0.6,0.7,0.8)$ & $(0.6,0.7,0.8)$ & $(0.6,0.7,0.8)$ & $(0.6,0.7,0.8)$ \\
\hline \multirow{4}{*}{ D2 } & $C_{1}$ & $(0.3,0.45,0.6)$ & $(0.3,0.45,0.6)$ & $(0.3,0.45,0.6)$ & $(0.3,0.45,0.6)$ & $(0.3,0.45,0.6)$ \\
\cline { 2 - 7 } & $C_{\vdots}$ & $\vdots$ & $\vdots$ & $\vdots$ & $\vdots$ & $\vdots$ \\
\cline { 2 - 7 } & $C_{32}$ & $(0.6,0.7,0.8)$ & $(0.6,0.7,0.8)$ & $(0.6,0.7,0.8)$ & $(0.6,0.7,0.8)$ & $(0.6,0.7,0.8)$ \\
\hline \multirow{4}{*}{ D3 } & $C_{1}$ & $(0.6,0.7,0.8)$ & $(0.3,0.45,0.6)$ & $(0.3,0.45,0.6)$ & $(0.6,0.7,0.8)$ & $(0.6,0.7,0.8)$ \\
\cline { 2 - 7 } & $C_{\vdots}$ & $\vdots$ & $\vdots$ & $\vdots$ & $\vdots$ & $\vdots$ \\
\cline { 2 - 7 } & $C_{32}$ & $(0.6,0.7,0.8)$ & $(0.6,0.7,0.8)$ & $(0.6,0.7,0.8)$ & $(0.6,0.7,0.8)$ & $(0.6,0.7,0.8)$ \\
\hline \multirow{4}{*}{ D4 } & $C_{1}$ & $(0.8,1,1)$ & $(0.6,0.7,0.8)$ & $(0.6,0.7,0.8)$ & $(0.1,0.2,0.3)$ & $(0.6,0.7,0.8)$ \\
\cline { 2 - 7 } & $C_{\vdots}$ & $\vdots$ & $\vdots$ & $\vdots$ & $\vdots$ & $\vdots$ \\
\cline { 2 - 7 } & $C_{32}$ & $(0.6,0.7,0.8)$ & $(0.3,0.45,0.6)$ & $(0.3,0.45,0.6)$ & $(0.8,1,1)$ & $(0.8,1,1)$ \\
\hline \multirow{3}{*}{ D5 } & $C_{1}$ & $(0.6,0.7,0.8)$ & $(0.6,0.7,0.8)$ & $(0.6,0.7,0.8)$ & $(0,0,0.1)$ & $(0.3,0.45,0.6)$ \\
\cline { 2 - 7 } & $C_{\vdots}$ & $\vdots$ & $\vdots$ & $\vdots$ & $\vdots$ & $\vdots$ \\
\cline { 2 - 7 } & $C_{32}$ & $(0.6,0.7,0.8)$ & $(0.3,0.45,0.6)$ & $(0.3,0.45,0.6)$ & $(0.6,0.7,0.8)$ & $(0.3,0.45,0.6)$ \\
\hline
\end{tabular}

Table 5: Effective component weights using fuzzy AHP

\begin{tabular}{|c|c|c|c|}
\hline Criteria & Weights & Sub Criteria & Weights \\
\hline \multirow{3}{*}{$\begin{array}{l}\text { Effect of existing } \\
\text { project portfolio }\end{array}$} & \multirow{3}{*}{0.198194} & $\begin{array}{l}\text { Impact of financial forecast turnover this project } \\
\text { with existing projects }\end{array}$ & 0.038054041 \\
\hline & & $\begin{array}{l}\text { Employer work experience of the running } \\
\text { projects }\end{array}$ & 0.075914248 \\
\hline & & $\begin{array}{l}\text { Impact of resources required for the new project } \\
\text { on the resources of ongoing projects }\end{array}$ & 0.084225513 \\
\hline \multirow{10}{*}{ Project specifications } & \multirow{10}{*}{0.248486} & Experience the same work & 0.005121048 \\
\hline & & Project duration & 0.020872824 \\
\hline & & Access to new technology & 0.003825442 \\
\hline & & Simple project & 0.012898163 \\
\hline & & Project Transparency & 0.022727027 \\
\hline & & Execution of project scheduling & 0.039454856 \\
\hline & & $\begin{array}{l}\text { The importance of the project for } \\
\text { future success }\end{array}$ & 0.043225134 \\
\hline & & Availability of technical requirements & 0.031240902 \\
\hline & & $\begin{array}{l}\text { Understanding the geographic conditions of the } \\
\text { project }\end{array}$ & 0.038122722 \\
\hline & & $\begin{array}{l}\text { Capability to build with proposed } \\
\text { implementation method }\end{array}$ & 0.036615903 \\
\hline \multirow{5}{*}{$\begin{array}{l}\text { Environmental, social and } \\
\text { political considerations }\end{array}$} & \multirow{5}{*}{0.262069} & Conforms to new industry standards & 0.010099615 \\
\hline & & According to the needs of customers & 0.032832266 \\
\hline & & $\begin{array}{l}\text { The importance of the plan in terms of national } \\
\text { security }\end{array}$ & 0.044360944 \\
\hline & & Consistency with environmental regulations & 0.048382655 \\
\hline & & $\begin{array}{l}\text { Degree of political significance at the national } \\
\text { and international level }\end{array}$ & 0.062542767 \\
\hline
\end{tabular}




\begin{tabular}{|c|c|c|c|}
\hline Criteria & Weights & Sub Criteria & Weights \\
\hline & & $\begin{array}{l}\text { Health, safety and environmental considerations } \\
\text { of the project }\end{array}$ & 0.063850753 \\
\hline \multirow{13}{*}{ Organizational considerations } & \multirow{13}{*}{0.291251} & Organization workload & 0 \\
\hline & & Influence on new commercial markets & 0 \\
\hline & & Satisfaction rate of project stakeholders & 0 \\
\hline & & $\begin{array}{l}\text { The presence of technology required to be } \\
\text { implemented }\end{array}$ & 0.013332597 \\
\hline & & $\begin{array}{l}\text { The existence of underlying systems for } \\
\text { implementation }\end{array}$ & 0.005800555 \\
\hline & & $\begin{array}{l}\text { Upgrading the capabilities of the institution and } \\
\text { transfer of knowledge }\end{array}$ & 0.014914381 \\
\hline & & $\begin{array}{l}\text { Understanding, cooperation and commitment in } \\
\text { all levels of management }\end{array}$ & 0.018510457 \\
\hline & & Senior management support & 0.031198225 \\
\hline & & Intermediate managers support & 0.023963259 \\
\hline & & $\begin{array}{l}\text { Adaptation of the project to the goals and } \\
\text { strategies of the organization }\end{array}$ & 0.038014081 \\
\hline & & Political acceptance of the project & 0.051723265 \\
\hline & & $\begin{array}{l}\text { Understanding engineering consultant with } \\
\text { project }\end{array}$ & 0.042005967 \\
\hline & & Availability of time and experienced staff & 0.051788214 \\
\hline
\end{tabular}

Table 6: The relative closeness to the ideal solution

\begin{tabular}{|c|c|c|c|c|c|}
\hline $\mathrm{C}_{l 1}$ & $\mathrm{C}_{l 1}$ & $\mathrm{C}_{l 2}$ & $\mathrm{C}_{l 3}$ & $\mathrm{C}_{l 4}$ & $\mathrm{C}_{l 5}$ \\
\hline$C_{l i}^{+}$ & 0.574702388 & 0.607086342 & 0.607086342 & 0.529687236 & 0.594500235 \\
\hline
\end{tabular}

The alternative $C_{l i}^{+}$with the highest value would be considered as the first rank and the lowest value is represented as the last rank. Therefore, the ranking order of five projects will be as follows: $A_{2} \approx A_{3}>A_{5}>A_{1}>A_{4}$. So, $A_{2}$ and $A_{3}$ Rajaie Bridge and Nokhbegan Footbridge are the best projects among the five projects, and $A_{4}$ is the worst project.

\section{CONCLUSION}

The work complexity and the interference of many parameters affecting the success factors of the projects on one hand, and the dependencies and effects that the organization's projects manipulate on each other make the topic of the project portfolio very important. This paper extracted some effective factors for selecting the best project portfolio through fuzzy Delphi method and consequently determined weights of the criteria by using fuzzy AHP method. Fuzzy TOPSIS method was then used to evaluate municipality projects by a group of experts by linguistic terminologies. The results showed that the "Impact of resources required for the new project on the resources of ongoing projects" criterion was more important than other criteria. According to the proposed methodology, Rajaie Bridge and Nokhbegan
Footbridge were selected as the best among the five ongoing projects.

\section{REFERENCES}

Ahmad, N., Kasim, M. M., \& Rajoo, S. S. K. (2016). Supplier Selection Using a Fuzzy Multi-criteria Method. International Journal of Industrial Management, 2, 61-71.

Alinezhad, A., \& Simiari, K. (2013). A Hybrid Method for Project Selection by Using DEMATEL/DEA. Journal of Industrial Management Studies, 11(28), 41-60.

Anisseh, M., Piri, F., Shahraki, M. R., \& Agamohamadi, F. (2012). Fuzzy extension of TOPSIS model for group decision making under multiple criteria. Artificial Intelligence Review, 38(4), 325-338.

Bashiri, M., \& Badri, H. (2010). A group decision making procedure for fuzzy interactive linear assignment programming. Expert Systems with Applications, 38(5), 5561-5568.

Chou, S.-Y., Chang, Y.-H., \& Shen, C.-Y. (2008). A fuzzy simple additive weighting system under group decision-making for facility location selection with objective/subjective attributes. European Journal of Operational Research, 189(1), 132-145.

Chuu, S. J. (2009). Group decision-making model using fuzzy multiple attributes analysis for the evaluation of advanced manufacturing technology. Fuzzy Sets and Systems, 160(5), 586-602.

Dubois, D., \& Prade, H. (1978). Operations on Fuzzy Numbers. International Journal of Systems Science, 9(6), 613-626. 
Ertuğrul, İ., \& Karakaşoğlu, N. (2009). Performance Evaluation of Turkish Cement Firms with Fuzzy Analytic Hierarchy Process and TOPSIS Methods. Expert Systems with Applications, 36(1), 702-715.

Ertuğrul, İ., \& Tuş, A. (2007). Interactive Fuzzy Linear Programming and an Application Sample at a Textile Firm. Fuzzy Optimization and Decision Making, 6(1), 29-49.

Fan, Z.-P., Ma, J., \& Zhang, Q. (2002). An approach to multiple attribute decision making based on fuzzy preference information on alternatives. Fuzzy Set and System, 131(1), 101-106.

Herrera, F., \& Martínez, L. (2001). A model based on linguistic 2-tuples for dealing with multigranular hierarchical linguistic contexts in multi-expert decision-making. IEEE Transactions on Systems, Man, and Cybernetics, Part B (Cybernetics), 31(2), $227-234$

Hwang, C. L., \& Yoon, K. P. (1995). Multiple attribute decision making: An introduction. London: Sage Publication.

Kahraman, C., Ateş, N. Y., Çevik, S., Gülbay, M., \& Erdoğan, S. A. (2007). Hierarchical fuzzy TOPSIS model for selection among logistics information technologies. Journal of Enterprise Information Management, 20(2), 143-168.

Kaufmann, A., \& Gupta, M. M. (1991). Introduction of fuzzy arithmetic: Theory and applications. New York: Van Nostrand Reinhold.

Liu, C.-H., \& Wu, H.-H. (2007). The Development of a Model to Explain Group Decision Making Process: An Application of Fuzzy Methodology. International Journal of Management, 24(3), 489498.

Mahdavi, I., Mahdavi-Amiri, N., Heidarzade, A., \& Nourifar, R. (2008). Designing a model of fuzzy TOPSIS in multiple criteria decision making. Applied Mathematics and Computation, 206(2), 607617.

Önüt, S., Kara, S. S., \& Efendigil, T. (2008). A hybrid fuzzy MCDM approach to machine tool selection. Journal of Intelligent Manufacturing, 19(4), 443453.
PMI. The Project Management Institute, from https://www.pmi.org/

Rabieh, M., \& Faddaie, A. (2015). Fuzzy mathematical model Selection of project portfolio and its solution using a multi-objective differential algorithm. Journal of Industrial Management Perspective, 19, 65-90.

Ravanshadnia, M., \& Jahromi, H. R. A. (2015). From project management to portfolio management: Fadak Isatis Publishing.

Saghafian, S., \& Hejazi, S. R. (2005). Multi-criteria Group Decision Making Using A Modified Fuzzy TOPSIS Procedure. Paper presented at the International Conference on Computational Intelligence for Modelling, Control and Automation, and International Conference on Intelligent Agents, Web Technologies and Internet Commerce.

Simões-Marques, M., Ribeiro, R. A., \& GameiroMarques, A. (2000). A fuzzy decision support system for equipment repair under battle conditions. Fuzzy Set and System, 115(1), 141-157.

Tsao, C.-T. (2006). A fuzzy MCDM approach for stock selection. Journal of the Operational Research Society, 57(11), 1341-1352.

Tsaur, S. H., Chang, T. Y., \& Yen, C. H. (2002). The evaluation of airline service quality by fuzzy MCDM. Tourism Management, 23(2), 107-115.

Wang, J.-W., Cheng, C.-H., \& Huang, K.-C. (2009). Fuzzy hierarchical TOPSIS for supplier selection. Applied Soft Computing, 9(1), 377-386.

Wang, Y.-J., \& Lee, H.-S. (2007). Generalizing TOPSIS for fuzzy multiple-criteria group decision-making. Computers \& Mathematics with Applications, 53(11), 1762-1772.

Yeh, C.-H., \& Chang, Y.-H. (2008). Modeling subjective evaluation for fuzzy group multicriteria decision making. [doi: DOI: 10.1016/j.ejor.2007.12.029]. European journal of Operational Research, 194(2), 464-473.

Zadeh, L. A. (1965). Fuzzy sets. Information and Control, 8(3), 338-353.

\title{
NAJBOLJI IZBOR PORTFOLIJA PROJEKTA KORIŠĆENJEM FAZI AHP I FAZI TOPSIS
}

\begin{abstract}
Izbor optimalnog portfolija projekata je jedna od najvažnijih i strateških odluka u većini organizacija, naročito u projektnim organizacijama. Pitanje izbora projekata je periodična aktivnost u odabiru odgovarajućeg i optimalnog portfolia predloženih projekata i tekućih projekata u okviru organizacije, koja može ispuniti ciljeve organizacije bez gubitka sredstava i uzimajući u obzir određena ograničenja. Shodno tome, cilj ovog rada je da se odabere najbolji portfolio projekta sa metodama fazi AHP i fazi TOPSIS. Pomenute metode su korišćene u studiji slučaja, a rezultati i podaci su ocenjeni sa različitih gledišta.
\end{abstract}

Ključne reči: Projekat, Portfolio projekata, Upravljanje projektnim portfolijom, Fazi AHP, Fazi TOPSIS. 